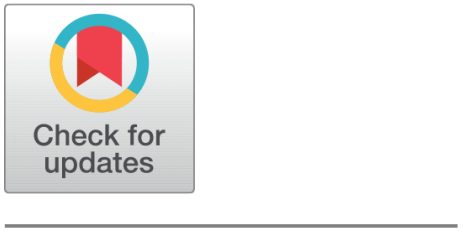

OPEN ACCESS

Received: 04-07-2020

Accepted: 27-08-2020

Published: 11-09-2020

Editor: Dr. Natarajan Gajendran

Citation: Beloor V, Swamy CJ, Nanjundeswaraswamy TS, Swamy DR, Nagesh P (2020) A study on job satisfaction and employee welfare in garment industries. Indian Journal of Science and Technology 13(33): 3445-3456. https ://doi.org/10.17485/IJST/v13i33.1058

* Corresponding author.

Tel: 9901581863

vanishreeblr@gmail.com

Funding: None

Competing Interests: None

Copyright: (c) 2020 Beloor et al. This is an open access article distributed under the terms of the Creative Commons Attribution License, which permits unrestricted use, distribution, and reproduction in any medium, provided the original author and source are credited.

Published By Indian Society for Education and Environment (iSee)

ISSN

Print: 0974-6846

Electronic: 0974-5645

\section{A study on job satisfaction and employee welfare in garment industries}

\author{
Vanishree Beloor ${ }^{1 *}$, Chaya J Swamy ${ }^{2}$, T S Nanjundeswaraswamy ${ }^{3}$, \\ D R Swamy4, P Nagesh ${ }^{5}$
}

1 Assistant professor, Department of Industrial Engineering and Management, JSS Academy of Technical Education, Bangalore, 560060, India. Tel.: 9901581863

2 Assistant Professor, Department of Management Studies, JSS Academy of Technical Education,, Bangalore, 560060, India

3 Associate Professor, Department of Mechanical Engineering, JSS Academy of Technical Education, Bangalore, 560060, India

4 Professor, Department of Industrial Engineering and Management, JSS Academy of Technical Education, Bangalore, 560060, India

5 Professor, Center for Management studies, Sri Jayachamarajendra College of Engineering, Mysuru, 570006, India

\section{Abstract}

Objectives: To analyze the impact of welfare facilities on Job satisfaction of employees working in garment industries. Method: The Research design chosen is descriptive in nature. The convenience sampling technique was employed, a total of 224 responses were collected from 51 garment industries located in and around Bangalore region, Karnataka State in India during 2020. Based on the research objectives, a questionnaire is prepared consisting of 63 items from eight components of Job satisfaction and Employee welfare, questionnaires was designed in five point Likert scale. The collected data were analyzed through the percentage analysis, Chi Square analysis and Pearson correlation analysis using SPSS and Minitab Software. Findings: The findings of the study showed that there is an association between welfare facilities provided and satisfaction in job. The study explored that welfare facilities significantly impact on the job satisfaction. Analysis also reveals that experience, education level and salary of an employee have associated with the job satisfaction. From the co relation analysis it is evident about the component training and development $(r=0.69)$ being highly correlated to job satisfaction while facility ( $r=0.47)$ is least correlated to job satisfaction. Whereas, personal benefits $(r=0.55)$ is moderately correlated to employee welfare, while health benefits $(r=0.33)$ is least correlated to employee welfare. Application: Present study helps policymakers to take decision about the welfare facilities to enhance the job satisfaction and productivity of the garment industries.

Keywords: Job Satisfaction; work environment; employee welfare; personal facilities; health facilities; garments 


\section{Introduction}

Indian sub-continent is the second largest manufacturer of garments after China being the global leader in garment production. India is known for its high quality garments and most of the garment manufacturers are in the Small and Medium scale. The garment industry is one of major sector contributing to the Indian economy it also contributes substantially to Indian GDP rate. Henceforth, any organization should focus on achieving employee satisfaction and employee welfare to ensure higher rate of productivity resulting in more revenues for the organization.

Any organization can fetch maximum output from employees only if employees are loving and committed towards their job, similarly on other flip they are able to fulfill their needs, and they feel a sort of motivation when they get what they really are in need of. Job satisfaction can be enhanced by providing welfare facilities and schemes ${ }^{(1)}$. Job satisfaction is multifarious theory in which employee's attitude and inner mental state is measured through which it helps in balancing employer and employee bonding ${ }^{(2)}$. According to ${ }^{(3)}$ an employee will give maximum output and work ideally when he is happy and content at his workplace is called satisfaction in job. The most valuable resource of an organization is Satisfied workers and most insignificant are the dissatisfied ones ${ }^{(4)}$. It is incentive system, flexible hours of work, supervisor relationship, career growth, recognition of work, unbiased work atmosphere and relationship with coworkers are key factors that has to be accounted for total Job satisfaction says ${ }^{(5)}$. Career and welfare management, Job design and analysis, planning, selection, hiring of human resources, health and safety, disciplinary and movement of employees are some of the key elements of Human resource management. Management of employee welfare among all is noting element of $\mathrm{HRM}^{(6)}$. In this stretch the authors ${ }^{(6)}$ defined Employee welfare as 'providing facilities and comforts to organizational employees in order to provide them a better living style. Employee welfare facilities help in creating a satisfied work environment with making a way to peace in industrial sector thereby getting better output from employees to employers says ${ }^{(7)}$. There are numerous studies trying to figure out the ground relationship between Job satisfaction and Employee welfare. Results from researchers in divergent fields ${ }^{(8-10)}$ say that there is a positive association between Job satisfaction and employee welfare. Providing constitutional and non-constitutional welfare measures to employees is important to leave them satisfied and satisfied employees in return provide outstanding output to the organization. Also results highlight the necessity of knowing the status of Employee welfare in selected field for which knowing the status becomes primary objective of this research. Conversely, there is a gap in the pragmatic understanding with regard to the employee welfare and job satisfaction in garment sector in the Indian scenario. At this juncture knowing the status of job satisfaction is considered as the second objective, followed by this the next objective framed is to know the relationship between these employees' welfare and job satisfaction. Any study is incomplete without the demographic study and its influence on employee welfare and job satisfaction. In line with this knowing the relationship between demographical variables and employee welfare and job satisfaction was one more noted objective of the current study.

In order to find out the existing gap in the present research and apply suitable theory to come out with better results reviewing of literature is important. In this context Employee welfare and Job satisfaction papers were reviewed thoroughly to know the status of welfare facilities in Garment sectors in India. Then its association with job satisfaction was also determined. Then the benefits of employee being satisfied in his work environment are also accounted. Employee welfare and Job satisfaction in garment sector few of them namely ${ }^{(11-14)}$ has made use of working conditions, canteen, restroom facilities, reward, compensation as some of the factors upholding the term employee welfare. It is also important here to note that very few studies that have reliable results have been conducted in this sector in Indian scenario. Also from the previous studies it is important here to note that most of the researchers have applied the concept of job satisfaction in various sectors and have measured its impact with positive outcomes. But on other hand we can see there are many studies on job satisfaction in garment industries but there are limited studies showing the impact of welfare facilities on job satisfaction in garment sector in Indian scenario. The present study is an attempt to explore the job satisfaction and welfare facilities in the selected garment industries.

\section{Employee welfare}

Employee welfare is a key factor in providing job satisfaction to employees according to various researchers in different fields. The research was an attempt by various researchers to know the association between employee welfare and job satisfaction and its effect on, development and productivity of organization ${ }^{(10,15-17)}$. The study was conducted at Garment industries in Bangladesh the results of which proved to have a positive association between welfare benefits, satisfaction of employees and productivity. The study proved in developing countries employee welfare can act as an instrument to corporate sustainability in Garment sector ${ }^{(15)}$. Researchers used different components of Employee welfare to measure its effectiveness some of them made use of compensation, Annual leave, family leave, child care programme, sick leave etc. to measure the main component, the results of which have a significant positive association between welfare facilities and job satisfaction ${ }^{(18)}$. According to author ${ }^{(19)}$ the study was conducted at Perfumery works in India to know the welfare facilities by considering components of 
welfare facilities as recreational facilities, Training and development, Pure drinking water facilities, sanitary facilities and safety measures provided to employees the results of which told about company providing better welfare facilities and employees in majority are satisfied with facilities provided as per their needs. The impact of welfare facilities provided to workers and its effect on performance in Public and private sector was measured by ${ }^{(20)}$ the results of which discovered employees in public sector are provided with better welfare facilities and comparatively they are more satisfied with facilities provided to them than private workers in India. The components of welfare facilities considered for study were Work environment, recreational, housing, sanitary and drinking water facilities, transportation, retirement benefits. One of the paper ${ }^{(21)}$ in sports field mentioned the need of welfare facilities through employee assistance programme such as motional, medical, insurance, investment, life skills and career development needs of employees. Research ${ }^{(22)}$ considered drinking water, canteen, grievance handling, medical and retirement benefits as welfare components to observe operation of industrial relations and level of satisfaction of employees with Employee welfare schemes in Rourkela steel plant, India. A study in chemical industry at Salem in India by ${ }^{(23)}$ has made use of proper canteen facilities, accommodation, travelling, recreational and medical facilities as components of employee welfare to see its effect on employee satisfaction. Research in IT Industries was also carried out by ${ }^{(24)}$ in labour welfare and social security measures provided to people working in IT sector. They considered factors for labour welfare schemes as labour management relation, rewards, motivation, labour welfare legislations, career planning opportunities for workers. Limited studies have made an attempt to find out the relationship between Employee welfare and job satisfaction in garment industries in India.

\section{Job satisfaction}

Job satisfaction can be alleged as employee's contentment with their jobs and it is one of the key elements in elevating the productivity of organization ${ }^{(25)}$. In developing countries due to lower employment rate and instability of economic status the main components of job satisfaction are Pay and promotion ${ }^{(26)}$. The study of Job satisfaction in Garments in Bangladesh ${ }^{(27)}$ has showed variables like working environment, salary structure, Job security, Hygiene canteen area, leave and medical facility has positive association and relation with coworkers and supervisors has poor relationship with job satisfaction. According to ${ }^{(28)}$ job satisfaction in Garment industry is influenced by stress, Wage policies, conditions at work and security in job. One of the studies on Employees job satisfaction ${ }^{(29)}$ conducted in garments at Bangalore region considered independent variables of Job satisfaction as current salary, working environment, safety and health facilities, promotion and leave policies, supervisor attitude, profits of working overtime. The results of the study showed working environment and pay were not satisfactory for employees. Study ${ }^{(30)}$ considered canteen and medical facility, work environment, supervisor relationship, satisfied timely pay as significantly manipulating variables of Job satisfaction. The factors such as, promotional opportunity, good relation with coworkers, management policy and recognition for better performance brings job satisfaction to the workers of garment industry in Bangladesh and the study has showed a positive link between job satisfaction and productivity as well ${ }^{(31)}$. The research on Job satisfaction among Banswara Garment workers in India include variables of Job satisfaction as benefits from salary, unbiased promotion policies, working conditions, leadership, supervisions and social relationships, the job itself ${ }^{(32)}$. Study among perceptions of self-efficacy and job satisfaction level between Korean and Non-Korean teachers ${ }^{(33)}$ used opportunities for promotion, workload, flow of communication, pay, recognition as variables of job satisfaction the results of which showed there is no insignificant difference on efficacy perception and satisfaction in job between Korean and Non-Korean teachers whereas on other flip there is a substantial healthy association between satisfaction in job and teacher efficacy.

From the plethora of literature, it is noticed that most of the researchers have used different interventions to quantify job satisfaction as it is a multi-dimensional construct. It is also noticed that few variables are consistently used in the research studies such as pay and compensation, working conditions, promotion, job security, Training \& Development, work environment, facilities, relation\& cooperation and compensation\& rewards and many others. From the literature following dimensions were selected based on the frequency of the usage of the researchers such as Work Environment; Relation \& Cooperation; Training \& Development; Compensation \& Rewards; Facilities; Job security; Health benefits; Personal benefits were considered for the present research.

Objectives of the study

Following are the research objectives framed:

1. To determine the status of welfare of employees in Garment sector.

2. To explore the employee job satisfaction level in Garment sector.

3. To know the relationship between job satisfaction and Employee welfare.

4. To know the relationship between demographical factors, job satisfaction and Employee welfare.

5. To find out the correlation among the components of job satisfaction and components of Employee welfare. 


\section{Methodology}

The Research design chosen is descriptive in nature. Based on the objectives framed, a sample questionnaire is prepared for preliminary pilot survey on Likert scale with ratings 5 as highest ranking and 1 as lowest ranking. The instrument consisted of 63 questions out of which 50 items comprising 6 components of Job satisfaction and 13 items covering 2 components of employee welfare. The prepared questionnaire will be administered to the target group.

Convenient sampling method was used to collect the relevant information through the questionnaires.

250 valid responses were collected from the 51 garment industries located in and around of Bangalore, Karnataka. Out of which only 224 were reliable and other 26 responses were discarded due to incomplete data. The research methodology will make use of quantitative approach to relate Job Satisfaction \& Employee Welfare.

\subsection{Design of questionnaire}

The questionnaires have been designed on the pretext of the six factors of job satisfaction and two factors of employee welfare that have been identified following thorough investigation of available literature based on the frequency of usage in previous studies. Following are the 6 dimensions of job satisfaction such as Work Environment; Relation \& Cooperation; Training \& Development; Compensation \& Rewards; Facilities; Job security and welfare facilities interventions like Health benefits and personal benefits were considered for the present study.

From the 224 respondents working in 51 garments data were collected.

Using five point Likert scale questionnaire was designed, rated on a scale ranging from "strongly agree to "strongly disagree". The questionnaire was designed and categorized in to the following sections,

- Demographical information related to both employees as well as firm.

- Employee's perception towards Job satisfaction.

- Employee's perception towards Employee welfare.

\subsection{Defining hypothesis}

Based on the stated objectives five hypotheses were formulated and tested for the acceptance using Chi-Square analysis. The alternative hypotheses were as follows.

$\mathrm{H}_{a 1}$ : There is an association between level of job satisfaction and demographical characteristics of employees

$\mathrm{H}_{a 2}$ : There is an association between level of employee's welfare facilities and demographical characteristics of employees.

$\mathrm{H}_{a 3}$ : There is an association between level of employee welfare and level of job satisfaction of employees

$\mathrm{H}_{a 4}$ : There is an association between personal benefits and level of job satisfaction of employees

$\mathrm{H}_{a 5}$ : There is an association between health benefits and level of job satisfaction of employees

\section{Findings and discussions}

This part delivers the results attained from the current study. These findings are presented based on the research questions that guided the research.

Demographical factors of employees mainly comprise of age, gender, experience, salary paid, type of job, education level, designation. The collected data was also analyzed to assess the status of Job satisfaction of employees and employee welfare. Refer ( Table 1).

Table 1. Number and percentage of demographical characteristics of workers

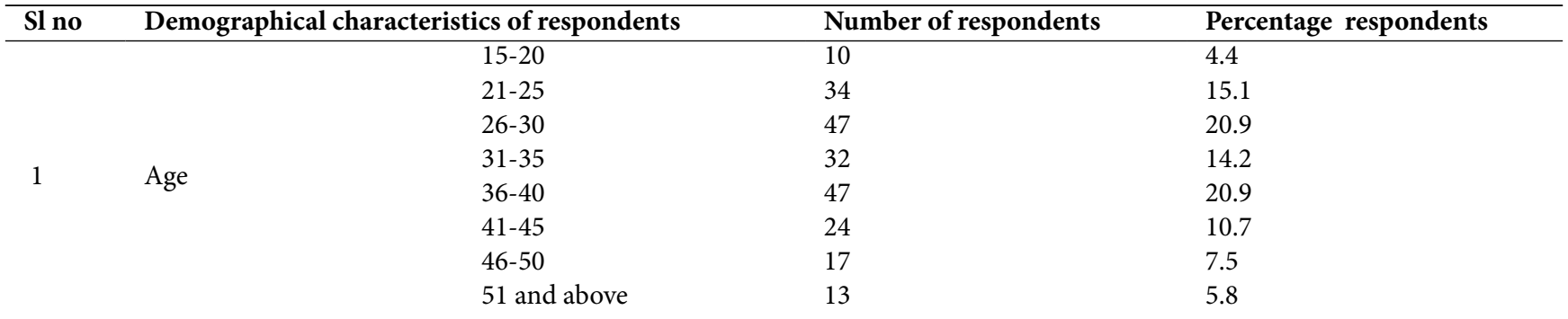

Continued on next page 


\begin{tabular}{|c|c|c|c|c|}
\hline \multicolumn{5}{|c|}{ Table 1 continued } \\
\hline \multirow{2}{*}{2} & \multirow{2}{*}{ Gender } & Male & 113 & 50.4 \\
\hline & & Female & 111 & 49.6 \\
\hline \multirow{3}{*}{3} & \multirow{3}{*}{ Experience } & up to 5 & 131 & 50.4 \\
\hline & & 6 to 10 & 59 & 26.3 \\
\hline & & More than 10 & 34 & 15.1 \\
\hline \multirow{2}{*}{4} & \multirow{2}{*}{ Type of job } & Technical & 23 & 10.2 \\
\hline & & Non-technical & 201 & 89.7 \\
\hline \multirow{5}{*}{5} & \multirow{5}{*}{ Education level } & PG & 0 & 0 \\
\hline & & Graduation & 1 & 0.1 \\
\hline & & Diploma & 3 & 1.33 \\
\hline & & ITI & 15 & 6.69 \\
\hline & & Others & 205 & 91.5 \\
\hline \multirow{4}{*}{6} & \multirow{4}{*}{ Salary } & $<5000$ & 0 & 0 \\
\hline & & $5000-10000$ & 129 & 57.5 \\
\hline & & $10000-20000$ & 79 & 35.2 \\
\hline & & more than 20000 & 16 & 7.14 \\
\hline
\end{tabular}

Among 224 workers who were surveyed, the analysis of data shows that around 58.48 percent of the workers have less than 5years of experience, around 26.33 percent of the employees have between 6-10 years of experience and around 15.19 percent of the employees are between 10-15 years of experience.

Around 0.5 percent of the workers are Graduates, around 1 percent of workers have attained an education level of diploma, around 7 percent of workers are ITI holders and around 91 percent of workers are with an education level below that of ITI.

Around 10.26 percent of workers belong to the Technical team and around 89.74 percent of workers belong to the NonTechnical team.Among the 224 workers who were surveyed, around 57.58 percent of workers average salary is in the range between 5000-10,000 around 35.26 percent of workers average salary is in the range between 10000-20000 and around 7.16 percent of workers average salary is more than 20,000 .

\subsection{Status of job satisfaction of employees in the surveyed RMG}

To analyze the overall Job satisfaction among the surveyed workers/employees they were basically divided as satisfied and unsatisfied employees based on the job satisfaction score that an individual obtained. For the current study, the overall mean so obtained is 4.23 .

Among the 224 surveyed workers, the analysis of data shows that around 50.44 percent of the respondents are satisfied and around 49.66 percent of the surveyed workers are unsatisfied as shown in ( Table 2). Percentage analysis addresses one of the objectives of the study about determining the status of Job satisfaction among employees.

Table 2. Status of job satisfaction of employees

\begin{tabular}{lll}
\hline Status of job satisfaction & Number of respondents & Percentage of respondents \\
\hline Satisfied & 113 & 50.4 \\
Unsatisfied & 111 & 49.6 \\
\hline
\end{tabular}

\subsection{Relationship between demographical characteristics and job satisfaction of employees}

In order to achieve the next framed objective of examining the association between demographical factors, Job satisfaction and employee welfare, six Hypothesis were framed. Chi square analysis was done using Minitab software, each of the hypotheses was tested for independency. Grounded on the view of the employees towards Job satisfaction they were grouped into two, namely satisfied and unsatisfied. The test statistics were represented in the ( Table 3). 
Table 3. Relationship between demographical characteristics and job satisfaction of employees

\begin{tabular}{|c|c|c|c|c|c|c|c|c|}
\hline Sl no & \multicolumn{2}{|c|}{$\begin{array}{l}\text { Demographical } \\
\text { characteristics of } \\
\text { employees }\end{array}$} & \multicolumn{2}{|c|}{$\begin{array}{l}\text { Status of job satisfaction of } \\
\text { employees }\end{array}$} & $\begin{array}{l}\text { Tablevalue } \\
\chi^{2}\end{array}$ & $\begin{array}{l}\text { CalculateValue } \\
\chi^{2}\end{array}$ & P value & $\begin{array}{l}\text { Significance } \\
\text { value }\end{array}$ \\
\hline \multirow{5}{*}{1} & \multirow{5}{*}{ Age } & $15-20$ & 5 & 5 & \multirow{5}{*}{14.067} & \multirow{5}{*}{3.141} & \multirow{5}{*}{0.872} & \multirow{5}{*}{ NS } \\
\hline & & $26-30$ & 25 & 22 & & & & \\
\hline & & $31-35$ & 16 & 16 & & & & \\
\hline & & $36-40$ & 19 & 28 & & & & \\
\hline & & 51 and above & 6 & 7 & & & & \\
\hline \multirow{2}{*}{2} & \multirow{2}{*}{ Gender } & Male & 46 & 67 & \multirow{2}{*}{3.841} & \multirow{2}{*}{1.125} & \multirow{2}{*}{0.289} & \multirow{2}{*}{ NS } \\
\hline & & Female & 53 & 58 & & & & \\
\hline \multirow[b]{2}{*}{3} & & up to 5 & 56 & 75 & \multirow[b]{2}{*}{5.991} & \multirow[b]{2}{*}{7.731} & \multirow[b]{2}{*}{0.02} & \multirow[b]{2}{*}{$5 \%$} \\
\hline & Experience & 6 to 10 & 35 & 24 & & & & \\
\hline \multirow{4}{*}{5} & \multirow{4}{*}{$\begin{array}{l}\text { Education } \\
\text { level }\end{array}$} & Graduation & 1 & 0 & \multirow{4}{*}{3.182} & & & \\
\hline & & Diploma & 2 & 1 & & 4.822 & - & $5 \%$ \\
\hline & & ITI & 4 & 11 & & & & \\
\hline & & Others & 106 & 99 & & & & \\
\hline & & $<5000$ & 0 & 0 & & & & \\
\hline & & $5000-10000$ & 56 & 73 & & & & \\
\hline 6 & Salary & $10000-20000$ & 45 & 34 & 7.75 & 3.859 & 0.021 & $5 \%$ \\
\hline & & $\begin{array}{l}\text { more than } \\
20000 \text { }\end{array}$ & 12 & 4 & & & & \\
\hline
\end{tabular}

Considering the Age of the employees, type of the job and gender ( $p>0.05, \chi^{2}$ calculated $<\chi^{2}$ table), since the calculated chi-square value is lesser than the Table chi-square value, demographical factors does not have a significant relationship with Job satisfaction. Therefore, Job satisfaction of employees is independent on the Age of the employees, type of the job and gender.

Considering the Experience of the employees, education and salary $\left(\mathrm{p}<0.05, \chi^{2}\right.$ calculated $>\chi^{2}$ table), since the calculated chi-square value is greater than the Table chi-square value, this demo-graphical factor has a significant relationship with Job satisfaction. Therefore, Job satisfaction of employees is dependent on the Experience of the employees, education and salary.

\subsection{Status of employee welfare among the surveyed respondents}

The numbers of workers who are satisfied and not satisfied are classified based on the grand mean, the present study grand mean is 3.34, above the grand mean is considered as satisfied and below the grand mean is considered as unsatisfied. The ( Table 4) represents the status of welfare interventions among respondents.

Table 4. Status of employee welfare of employees in the surveyed samples

\begin{tabular}{lll}
\hline Status of employee welfare & Number of respondents & Percentage of respondents \\
\hline Satisfied & 127 & 56.6 \\
Unsatisfied & 97 & 43.4 \\
\hline
\end{tabular}

Among the 224 workers who were gauged, the analysis of data shows that around 56.69 percent of the workers are satisfied and around 43.31 percent of the workers are unsatisfied.

\subsection{Relationship among demographical characteristics and status of welfare of employees}

To examine the association between demographical factors and welfare facilities, six hypotheses were established. Using Minitab software, each of the hypotheses was tested for independency by conducting chi-square analysis. Based on the view of the employees towards welfare facilities they were grouped in to two, namely satisfied and unsatisfied. The test statistics are showed 
in the ( Table 5). Considering the Age of the employees, type of job and education level of employees ( $p>0.05, \chi^{2}$ calculated $<\chi^{2}$ table), since the calculated chi-square value is lesser than the Table chi-square value, this demographical factor does not have a significant relationship with Employee welfare. Therefore, Employee welfare is independent on the Age of the employees, type of job and education level of employees.

Table 5. Relationship between demographical characteristics and welfare status of employees

\begin{tabular}{|c|c|c|c|c|c|c|c|c|}
\hline \multirow[t]{2}{*}{ Sl no } & \multirow{2}{*}{\multicolumn{2}{|c|}{$\begin{array}{l}\text { Demographical characteristics } \\
\text { of employees }\end{array}$}} & \multicolumn{2}{|c|}{$\begin{array}{l}\text { Status of Employee welfare } \\
\text { of Employees }\end{array}$} & \multirow[t]{2}{*}{$\begin{array}{l}\text { Table value } \\
\chi^{2}\end{array}$} & \multirow[t]{2}{*}{$\begin{array}{l}\text { Calculate } \\
\text { value } \chi^{2}\end{array}$} & \multirow[t]{2}{*}{$\mathrm{P}$ value } & \multirow[t]{2}{*}{$\begin{array}{l}\text { Significance } \\
\text { value }\end{array}$} \\
\hline & & & Satisfied & Unsatisfied & & & & \\
\hline \multirow{8}{*}{1} & \multirow{8}{*}{ Age } & $15-20$ & 6 & 4 & \multirow{8}{*}{14.067} & \multirow{8}{*}{4.38} & \multirow{8}{*}{0.735} & \\
\hline & & $21-25$ & 17 & 17 & & & & \\
\hline & & $26-30$ & 29 & 18 & & & & \\
\hline & & $31-35$ & 16 & 16 & & & & \\
\hline & & $36-40$ & 27 & 20 & & & & \\
\hline & & $41-45$ & 17 & 7 & & & & \\
\hline & & $46-50$ & 9 & 8 & & & & \\
\hline & & 51 and above & 6 & 7 & & & & \\
\hline \multirow{2}{*}{2} & \multirow{2}{*}{ Gender } & Male & 46 & 53 & \multirow{2}{*}{3.841} & \multirow{2}{*}{4.075} & \multirow{2}{*}{0.044} & \multirow{2}{*}{$5 \%$} \\
\hline & & Female & 75 & 50 & & & & \\
\hline \multirow{3}{*}{3} & \multirow{3}{*}{ Experience } & up to 5 & 64 & 67 & \multirow{3}{*}{5.991} & \multirow{3}{*}{8.682} & \multirow{3}{*}{0.013} & \multirow{3}{*}{$5 \%$} \\
\hline & & 6 to 10 & 42 & 17 & & & & \\
\hline & & More than 10 & 21 & 13 & & & & \\
\hline \multirow{2}{*}{4} & \multirow{2}{*}{ Type of job } & Technical & 17 & 6 & \multirow{2}{*}{3.841} & \multirow{2}{*}{3.095} & \multirow{2}{*}{0.079} & \\
\hline & & Non-technical & 110 & 91 & & & & \\
\hline \multirow{5}{*}{5} & \multirow{5}{*}{ Education level } & PG & 0 & 0 & \multirow{5}{*}{7.815} & & & \\
\hline & & Graduation & 1 & 0 & & & & \\
\hline & & Diploma & 1 & 2 & & 3.287 & - & \\
\hline & & ITI & 6 & 9 & & & & \\
\hline & & Others & 119 & 86 & & & & \\
\hline & & $<5000$ & 0 & 0 & & & & \\
\hline 6 & Sol & $5000-10000$ & 62 & 67 & 5091 & 3237 & 001 & $5 \%$ \\
\hline 0 & Salary & $10000-20000$ & 54 & 25 & 5.991 & 5.251 & 0.01 & $5 \%$ \\
\hline & & more than 20000 & 11 & 5 & & & & \\
\hline
\end{tabular}

Considering the gender, experience and salary of the employees $\left(\mathrm{p}<0.05, \chi^{2}\right.$ calculated $>\chi^{2}$ table), since the calculated chisquare value is greater than the Table chi-square value, this demo-graphical factor has a significant relationship with Employee welfare. Therefore, Employee welfare is dependent on the gender, experience and salary of the employees.

\subsection{Relationship between job satisfaction and employee welfare}

The objective of knowing the association between Job satisfaction and employee welfare is carried out by framing alternative hypothesis that is tested for association by using chi-square analysis. Based on the Employee welfare status the employees were grouped into two, namely satisfied and unsatisfied, the test statistics were represented in the ( Table 6).

Table 6. Relationship between job satisfaction and employee welfare

\begin{tabular}{|c|c|c|c|c|c|c|}
\hline \multirow{2}{*}{$\begin{array}{l}\text { Status of Job } \\
\text { satisfaction }\end{array}$} & \multicolumn{2}{|c|}{ Status of Employee welfare } & \multirow{2}{*}{$\begin{array}{l}\text { Table value } \\
\chi^{2}\end{array}$} & \multirow{2}{*}{$\begin{array}{l}\text { Calculated } \\
\text { value } \chi^{2}\end{array}$} & \multirow{2}{*}{ p value } & \multirow{2}{*}{$\begin{array}{l}\text { Significance } \\
\text { value }\end{array}$} \\
\hline & Satisfied & Unsatisfied & & & & \\
\hline Satisfied & 75 & 38 & \multirow{2}{*}{3.841} & \multirow{2}{*}{8.695} & \multirow{2}{*}{0.003} & \multirow{2}{*}{$5 \%$} \\
\hline Unsatisfied & 52 & 59 & & & & \\
\hline
\end{tabular}


From the chi square analysis, it is identified that $\mathrm{p}<0.05, \chi^{2}$ calculated $>\chi^{2}$ table, since the calculated chi-square value is greater than the Table chi-square value, it signifies that the Job satisfaction of the employees has significant association with Employee welfare. Therefore, Job satisfaction of the employees is dependent on the Employee welfare interventions of the employees. The results here accept alternative hypothesis Ha3 thereby rejecting null hypothesis.

\subsection{Status of components of job satisfaction}

The following ( Table 7) shows the number of employees satisfied and unsatisfied based on six components of job satisfaction.

Table 7. Status of components of job satisfaction

\begin{tabular}{llll}
\hline \multirow{2}{*}{ Sl no } & Component of job satisfaction & \multicolumn{2}{l}{ Number of employees } \\
\cline { 3 - 4 } & & Satisfied & Unsatisfied \\
\hline 1 & Work Environment & 161 & 63 \\
2 & Relation \& Co operation & 105 & 119 \\
3 & Training \& Development & 135 & 89 \\
4 & Compensation \& Rewards & 139 & 85 \\
5 & Facilities & 154 & 70 \\
6 & Job security & 139 & 85 \\
\hline
\end{tabular}

\subsection{Status of components of employee welfare}

The ( Table 8) shows the number of employees satisfied and unsatisfied based on two components of employee welfare.

Table 8. Status of components of employee welfare

\begin{tabular}{llll}
\hline \multirow{2}{*}{ Sl no } & \multirow{2}{*}{ Components of employee welfare } & \multicolumn{2}{l}{ Number of employees } \\
\cline { 3 - 4 } & & Satisfied & Unsatisfied \\
\hline 1 & Personal facilities & 139 & 85 \\
2 & Health facilities & 154 & 70 \\
\hline
\end{tabular}

\subsection{Relationship between personal facilities and components of job satisfaction}

To analyze the relationship between Personal benefit component and components of Job satisfaction, six alternative Hypotheses were established namely $\mathrm{Ha}_{1}, \mathrm{Ha}_{2}, \mathrm{Ha}_{3}, \mathrm{Ha}_{4}, \mathrm{Ha}_{5}$ and $\mathrm{Ha} 4$. Using Minitab Software, each of the hypotheses was tested for association by conducting chi-square analysis. Based on the perception of the employees towards all the six components of Job satisfaction under personal benefit component they were grouped into two, namely satisfied and unsatisfied. Also, after the chi-square analysis, the values $\chi^{2}$ and the significance levels are presented in the ( Table 9).

Table 9. Relationship between personal facilities component and components of job satisfaction.

\begin{tabular}{|c|c|c|c|c|c|c|c|c|}
\hline \multirow{2}{*}{$\begin{array}{l}\text { Sl } \\
\text { no }\end{array}$} & \multirow{2}{*}{\multicolumn{2}{|c|}{ Component of Job satisfaction }} & \multicolumn{2}{|c|}{ Personal facilities } & \multirow{2}{*}{$\begin{array}{l}\text { Table } \\
\text { value } \chi^{2}\end{array}$} & \multirow{2}{*}{$\begin{array}{l}\text { Calculate } \\
\text { value } \chi^{2}\end{array}$} & \multirow{2}{*}{$P$ value } & \multirow{2}{*}{$\begin{array}{l}\text { Significance } \\
\text { value }\end{array}$} \\
\hline & & & Satisfied & Unsatisfied & & & & \\
\hline \multirow{2}{*}{1} & Work Fnyironment & Satisfied & 97 & 72 & \multirow{2}{*}{3.841} & \multirow{2}{*}{5.043} & \multirow{2}{*}{0.02} & \multirow{2}{*}{$5 \%$} \\
\hline & work Environment & Unsatisfied & 22 & 33 & & & & \\
\hline \multirow{2}{*}{2} & Relation \& Co & Satisfied & 64 & 41 & \multirow{2}{*}{3.841} & \multirow{2}{*}{4.863} & \multirow{2}{*}{0.02} & \multirow{2}{*}{$5 \%$} \\
\hline & operation & Unsatisfied & 55 & 64 & & & & \\
\hline \multirow{2}{*}{3} & Training \& & Satisfied & 60 & 48 & \multirow{2}{*}{3.841} & \multirow{2}{*}{0.495} & \multirow{2}{*}{0.48} & \multirow{2}{*}{ NS } \\
\hline & Development & Unsatisfied & 59 & 57 & & & & \\
\hline \multirow{2}{*}{4} & Compensation \& & Satisfied & 82 & 57 & \multirow{2}{*}{3.841} & \multirow{2}{*}{5.065} & \multirow{2}{*}{0.02} & \multirow{2}{*}{$5 \%$} \\
\hline & Rewards & Unsatisfied & 37 & 48 & & & & \\
\hline \multirow{2}{*}{5} & \multirow{2}{*}{ Facilities } & Satisfied & 40 & 29 & \multirow{2}{*}{3.841} & \multirow{2}{*}{0.94} & \multirow{2}{*}{0.33} & \multirow{2}{*}{ NS } \\
\hline & & Unsatisfied & 79 & 76 & & & & \\
\hline \multirow{2}{*}{6} & \multirow{2}{*}{ Job security } & Satisfied & 85 & 69 & \multirow{2}{*}{3.841} & \multirow{2}{*}{0.848} & \multirow{2}{*}{0.357} & NS \\
\hline & & Unsatisfied & 34 & 36 & & & & NS \\
\hline
\end{tabular}


From the Chi Square analysis it is revealed that Work Environment, Relation \& Co-operation and Compensation \& Rewards are significantly associated with personal facilities $\left(\mathrm{p}<0.05, \chi^{2}\right.$ calculated $)$ on the other hand Training \& Development, facilities and Job security are not associated with personal facilities $\left(\mathrm{p}>0.05, \chi^{2}\right.$ calculated $<\chi^{2}$ table).

\subsection{Relationship between health benefit component and components of job satisfaction}

To analyze the relationship between Health benefit component and components of Job satisfaction, six alternative Hypotheses were established namely $\mathrm{Ha}_{1}, \mathrm{Ha}_{2}, \mathrm{Ha}_{3}, \mathrm{Ha}_{4}, \mathrm{Ha} 5_{5}$ and $\mathrm{Ha} 5$. Using Minitab Software, each of the alternative hypotheses was tested for association by conducting chi-square analysis. Based on the perception of the employees towards all the six components of Job satisfaction under health benefit component they were grouped into two, namely satisfied and unsatisfied. Also, after the chi-square analysis, the values $\chi^{2}$ and the significance levels are presented in the ( Table 10).

Table 10. Relationship between health facilities component and components of job satisfaction.

\begin{tabular}{|c|c|c|c|c|c|c|c|c|}
\hline \multirow{2}{*}{ Sl no } & \multirow{2}{*}{\multicolumn{2}{|c|}{ Component of Job satisfaction }} & \multicolumn{2}{|c|}{ Health facilities } & \multirow{2}{*}{$\begin{array}{l}\text { Table } \\
\text { value } \chi^{2}\end{array}$} & \multirow{2}{*}{$\begin{array}{l}\text { Calculate } \\
\text { value } \chi^{2}\end{array}$} & \multirow{2}{*}{$P$ value } & \multirow{2}{*}{$\begin{array}{l}\text { Significance } \\
\text { value }\end{array}$} \\
\hline & & & Satisfied & Unsatisfied & & & & \\
\hline \multirow{2}{*}{1} & \multirow{2}{*}{ Work Environment } & Satisfied & 103 & 66 & \multirow{2}{*}{3.841} & \multirow{2}{*}{3.177} & \multirow{2}{*}{0.07} & \multirow{2}{*}{ NS } \\
\hline & & Unsatisfied & 26 & 29 & & & & \\
\hline \multirow{2}{*}{2} & \multirow{2}{*}{$\begin{array}{l}\text { Relation \& Co } \\
\text { operation }\end{array}$} & Satisfied & 70 & 35 & \multirow{2}{*}{3.841} & \multirow{2}{*}{6.668} & \multirow{2}{*}{0.01} & \multirow{2}{*}{ Significant } \\
\hline & & Unsatisfied & 59 & 60 & & & & \\
\hline \multirow{2}{*}{3} & \multirow{2}{*}{$\begin{array}{l}\text { Training \& } \\
\text { Development }\end{array}$} & Satisfied & 68 & 40 & \multirow{2}{*}{3.841} & \multirow{2}{*}{2.466} & \multirow{2}{*}{0.11} & \multirow{2}{*}{ NS } \\
\hline & & Unsatisfied & 61 & 55 & & & & \\
\hline \multirow{2}{*}{4} & \multirow{2}{*}{$\begin{array}{l}\text { Compensation \& } \\
\text { Rewards }\end{array}$} & Satisfied & 89 & 50 & \multirow{2}{*}{3.841} & \multirow{2}{*}{6.219} & \multirow{2}{*}{0.07} & \multirow{2}{*}{ Significant } \\
\hline & & Unsatisfied & 40 & 45 & & & & \\
\hline \multirow{2}{*}{5} & \multirow{2}{*}{ Facilities } & Satisfied & 52 & 17 & \multirow{2}{*}{3.841} & \multirow{2}{*}{12.896} & \multirow{2}{*}{0} & \multirow{2}{*}{ Significant } \\
\hline & & Unsatisfied & 77 & 78 & & & & \\
\hline \multirow{2}{*}{6} & Johs s s s & Satisfied & 87 & 67 & 3841 & 0242 & 0.62 & NS \\
\hline & ob security & Unsatisfied & 42 & 28 & 3.841 & 0.242 & 0.02 & NS \\
\hline
\end{tabular}

From the Chi Square analysis it is revealed that component Relation \& Co-operation, Compensation \& Rewards and Facilities are significantly associated with Health benefit component $\left(\mathrm{p}<0.05, \chi^{2}\right.$ calculated) on the other hand Work Environment, Training \& Development and Job security are not associated with Health benefit $\left(\mathrm{p}>0.05, \chi^{2}\right.$ calculated $<\chi^{2}$ table).

\subsection{Correlation analysis between components of job satisfaction}

Correlation is an analysis that measures the strengths of association between two variables and the direction of the relationship. In support to the stated fact the fifth objective of the study about finding the correlation between components of Job satisfaction was framed. The results of the correlation analysis carried out are tabulated as shown below ( Table 11). The results show that Training and development

Table 11. Correlation analysis between components of job satisfaction

\begin{tabular}{|c|c|c|c|c|c|c|c|}
\hline & $\begin{array}{l}\text { Job satis- } \\
\text { faction }\end{array}$ & $\begin{array}{l}\text { Work envi- } \\
\text { ronment }\end{array}$ & $\begin{array}{l}\text { Relation and co } \\
\text { operation }\end{array}$ & $\begin{array}{l}\text { Training \& } \\
\text { Development }\end{array}$ & Compensation & $\begin{array}{l}\text { Job secu- } \\
\text { rity }\end{array}$ & Facility \\
\hline Job satisfaction & 1 & & & & & & \\
\hline Work environment & 0.55 & 1 & & & & & \\
\hline Relation and co operation & 0.51 & 0.22 & 1 & & & & \\
\hline Training\&development & 0.69 & 0.27 & 0.48 & 1 & & & \\
\hline Compensation & 0.59 & 0.28 & 0.19 & 0.24 & 1 & & \\
\hline Job security & 0.53 & -0.04 & 0.008 & 0.21 & 0.24 & 1 & \\
\hline Facility & 0.47 & 0.09 & 0.064 & 0.200 & 0.08 & 0.16 & 1 \\
\hline
\end{tabular}

$(\mathrm{r}=0.69)$ is highly correlated to job satisfaction while Facility $(\mathrm{r}=0.47)$ is least correlated to job satisfaction 


\subsection{Correlation analysis between components of employee welfare}

The ( Table 12) presents the correlation between the selected two components of employee welfare. The result of the correlation analysis shows that personal benefits $(r=0.55)$ is highly correlated to employee welfare while health benefits $(r=0.33)$ is least correlated to employee welfare. Therefore, the fifth objective of the study about correlation between components of Employee welfare is analyzed.

Table 12. Correlation analysis between components of employee welfare

\begin{tabular}{llll}
\hline & EMPLOYEE WELFARE & HEALTH FACILITIES & PERSONAL FACILITIES \\
\hline EMPLOYEE WELFARE & 1 & & \\
HEALTH FACILITIES & 0.333964 & 1 & 1 \\
PERSONAL FACILITIES & 0.557099 & 0.419893 & \\
\hline
\end{tabular}

\section{Discussion}

The research findings give confirmation that better welfare facilities lead to augmented satisfaction in job among workers. The findings are as per the defined five objectives of the study that are subjected to statistical techniques to obtain results. Findings of several authors relating to employee welfare and job satisfaction are consistent with the results obtained in current study. ${ }^{(34-36)}$. The findings of the current study indicated about $50 \%$ of workers are satisfied with their current job and $56.69 \%$ of workers are satisfied with welfare facilities provided. The study also revealed about demographical factors such as age and gender are not associated with Employee welfare whereas Type of job, experience and salary have their impact welfare facilities provided. Additionally, the results of percentage analysis for relationship between the Job satisfaction and employee welfare of the respondents, it is inferred that when employees are satisfied with welfare facilities then they have high job satisfaction. The results are in line with the findings of author ${ }^{(8)}$ who told components of welfare facilities are highly correlated to job satisfaction. According to authors ${ }^{(8,37)}$ Job satisfaction is influenced by salary, supervisor relationship, promotion, housing facility and security of job. The existing study from chi-square analysis determined about components of job satisfaction such as work environment, relation \& cooperation and compensation \& rewards have a significant association with the personal benefits and with respect to health measures provided by garments. It is evidenced that components of job satisfaction namely facilities, relation \& cooperation and compensation \& rewards have a significant association with the health benefits. The results of author ${ }^{(1)}$ revealed the status of welfare facilities in garment industries among Sri Lankan employees is positively correlated with job satisfaction with some employees being satisfied and some not satisfied with the present welfare measures such as reward system, safety and canteen facility. The fifth objective framed on correlation resulted with Training and development $(\mathrm{r}=0.69)$ being highly correlated to job satisfaction while Facility $(\mathrm{r}=0.47)$ being least correlated to job satisfaction. Results of correlation analysis shows that personal benefits $(\mathrm{r}=0.55)$ is highly correlated to employee welfare while health benefits $(r=0.33)$ is least correlated to employee welfare. According to author ${ }^{(38)}$, the correlation analysis provide adequate statistical confirmation regarding the relationship between employee welfare facilities and job satisfaction that leads to improved productivity. Therefore, all five objectives were considered during methodological analysis of the study with the obtained results empirically proving the theoretical concepts considered during review.

\section{Conclusion}

The study proved that welfare facilities is important key component in ensuring job satisfaction of employees in Garment sector and satisfied employees retain longer and yield better productivity. In order to support the above statement an attempt was made in the study by framing objective of knowing the relationship between job satisfaction and employee welfare. The other subject of ensuring job satisfaction among workers in garment industries is addressed through this study by defining the objective of determining the status of welfare of employees in Garment sector. The results of the study showed workers opinion about welfare facilities provided and satisfaction in job. Also, the importance of knowing the association between demographical factors, job satisfaction and employee welfare was highlighted in the study, followed by finding out the highest and least correlated component of job satisfaction and employee welfare.

Therefore, explored results on employee job satisfaction suggest that Garment industries in Bangalore region should emphasis on refining their welfare facilities and job satisfaction components as almost $50 \%$ of employees still remain unsatisfied with welfare facilities provided that effect satisfaction in job among employees. This may eventually lead to hold back their best talent within the organization. This study is limited to Garment industries in India, Bangalore region. 


\section{References}

1) Almeida NA, Perera GD. The impact of welfare on job satisfaction among non managerial employees in the apparel industry in Sri Lanka. In: and others, editor. 2nd International HRM Conference 2015;vol. 2 of 1. . Available from: https://core.ac.uk/download/pdf/228546283.pdf.

2) Vasudevaiah S. Implementation Of Wage Incentive Schemes In Indian Railways - A Study Based On Employee Perception In Select Workshops. The International Journal of Engineering and Science (IJES). 2018;7(10):24-54. Available from: http://www.theijes.com/papers/vol7-issue10/Version1/D0710012454.pdf.

3) Wakida E, Lawther W, , University of Central Florida. Job satisfaction-a literature review on employee motivation, attitudes and turnover: what is the relationship?. 2014. Available from: https://d1wqtxts1xzle7.cloudfront.net/38998090.

4) Baghaei R. . Available from: https://shodhganga.inflibnet.ac.in/handle/10603/2009.

5) Prabakar S. Employees satisfaction \& welfare measures a case study with special reference to Don Bosco college of Arts \& Science, Sogathur, Dharmapuri. A peered review. Asia Pacific Journal of Research. 2013;3(10):1-11. Available from: https://rb.gy/xoi6wh.

6) Opatha HH. Human Resource Management. 2009. Available from: https://doi.org/10.31357/bkc.fmsc.00001.

7) Madhumathi M, Desai RG. Analysis of Pre and Post Reform Social Security and Labour Welfare Expenditures in Karnataka State Road Transport Corporation. Indian Journal of Industrial Relations. 2003;38(4):525-535. Available from: https://www.jstor.org/stable/27767869?seq=1.

8) Mendis MVS. Welfare facilities and job satisfaction: a study of operational level employees in the apparel industry of Sri Lanka. Kelaniya Journal of Human Resource Management. 2016;11. Available from: https://dx.doi.org/10.4038/kjhrm.v11i2.33.

9) Baluyos RG, Rivera LH, Baluyos LE. Teachers' Job Satisfaction and Work Performance. Open Journal of Social Sciences. 2019;07(08):206-221. Available from: https://dx.doi.org/10.4236/jss.2019.78015.

10) Muruu RW, Were S, Abok A. Effects of welfare programmes on employee satisfaction in the public sector: A case of the public service commission. The Strategic Journal of Business \& Change Management. 2016;3(4):1607-1640. Available from: http://strategicjournals.com/index.php/journal/article/view/ 401.

11) Jaishree MS. A study on labour welfare measures and its impact on employees' job satisfaction in Garment Industries. Tirupur International Journal in Management \& Social Science. 2015;3(4):86-95. Available from: http://www.indianjournals.com/ijor.aspx?target=ijor:ijmss\&volume=3\&issue=4\& article $=009$.

12) Tung HT, Anh NTV, Pt A. The Factors Impact on Employee Satisfaction in Work at Vietnamese Garment Enterprises. Open Journal of Business and Management. 2019;7(2):666-679. Available from: https://doi.org/10.4236/ojbm.2019.72045.

13) Hearle C. Skills, Employment and Productivity in the Garments and Construction Sectors in Bangladesh and elsewhere. and others, editor;Oxford Policy Management. 2016. Available from: https://rb.gy/o2kyo4.

14) Hiba JC, Intl Labour Organisation. Improving working conditions and productivity in the garment industry: An action manual. and others, editor. 1998. Available from: https://www.ilo.org/safework/info/instr/WCMS_228220/lang--en/index.html.

15) Nusrat M, Solaiman M. A Study of Employee Welfare Leading to Corporate Sustainability in Garments Industries of Bangladesh. Asian Business Review;6(1). Available from: https://doi.org/10.18034/abr.v6i1.776.

16) Afroz N. Factors affecting employee turnover in readymade garments sector of Bangladesh. International Journal of Multidisciplinary Research and Development. 2017;4(10):97-103.

17) Srivastava SK. Impact of Labour Welfare on Employee Attitudes and Job Satisfaction. Management and Labour Studies. 2004;29:31-41. Available from: https://dx.doi.org/10.1177/0258042x0402900103.

18) Musyoka S. Effect of Staff Welfare Programs on Employee Satisfaction among Commercial Banks in Kenya. . Available from: http://erepo.usiu.ac.ke/ handle/11732/626.

19) Farah SA. Employee Welfare Facilities and Job Satisfaction. Researchacies International Journal of Business and Management Studies. 2018;2(1):1-3.

20) Rao PV, Patro CS, Raghunath KM. Employee welfare is the key: an insight. International Journal of Business and Administration Research Review. 2015;3(11):40-47. Available from: https://rb.gy/9zxhdw.

21) Manzini H, Gwandure C. The Provision of Employee Assistance Programmes in South African Football Clubs: A Case Study. Journal of Social Sciences. 2011;27(2). Available from: https://doi.org/10.1080/09718923.2011.11892908.

22) Nanda N, Panda JK. Challenges and effectiveness of industrial relation environment in Indian Industries study on Rourkela Steel Plant. International Journal of financial services and management research. 2013;2(6):163-74.

23) Logasakthi K, Rajagopal K. A study on employee health, safety and welfare measures of chemical industry in the view of Salem Region. Management (IJRBM);1(1). Available from: https://d1wqtxts1xzle7.cloudfront.net/33272342/2-78-1371294846-1.

24) Rajkuar B. A Study on Labour Welfare Measures and Social Security in IT Industries with Reference to Chennai. International Journal of Enterprise Computing and Business Systems. 2014;4(1):1-1.

25) Mowla MM. Measuring the Factors Affecting Employees Job Satisfaction in Readymade Garments Industry: Bangladesh Perspective. International Journal of Advances in Agriculture Sciences. 2019;p. 17-23. Available from: http://kibanresearchpublications.com/journal/IJAAS/index.php/IJAAS/article/view/ 563.

26) Malik ME, Danish RQ, Munir Y. The Impact of Pay and Promotion on Job Satisfaction: Evidence from Higher Education Institutes of Pakistan. American Journal of Economics. 2012;2(4):6-9. Available from: https://dx.doi.org/10.5923/j.economics.20120001.02.

27) Khan AG, Huq SMU, Islam N. Job Satisfaction of Garments Industry in a Developing Country. Management Studies and Economic Systems. 2019;4(2):115122. Available from: http://www.msaes.org/article_85822.html.

28) Akter A, Wali SB, Kamal MR, Parvin MM. Factors affecting job satisfaction of working mothers of readymade garments sector in Bangladesh. Issues in Business Management and Economics. 2017;5(2):25-36. Available from: https://journalissues.org/wp-content/uploads/2017/03/Akter-et-al.pdf.

29) Haritha M, Nischitha H, Sunitha N. Employee’s View on Job Satisfaction: A Study on Garments Industry in Bangalore. . Available from: https: //pdfs.semanticscholar.org/ab33/16cb245fcdf52a86228a6f6b97e0f5293404.pdf.

30) Ferdous SR. Factors promoting work satisfaction of readymade garment (RMG) worker in Bangladesh: An empirical analysis. Journal of Scientific Research and Development. 2015;2(8):39-47. Available from: https://rb.gy/rc3cf3.

31) Bhuiyan NA. Measuring Job Satisfaction Level of Garment IndustrialWorkers in Bangladesh; A Case Study on Dhaka District. International Journal of Ethics in Social Sciences. 2015;3. Available from: http://www.crimbbd.org/wp-content/uploads/2016/05/3.2.7.pdf.

32) Shukla K, Singh A. To Study the factors affecting the job satisfaction and level of job satisfaction at Baswara Garments Ltd. The International Journal of Indian Psychology. 2016;3(9):1-5. Available from: http://oaji.net/articles/2016/1170-1465571372.pdf. 
33) Dipasupil RS, Ham JH, Min HJ. Relationship between Teachers Level of Job Satisfaction and Self-Efficacy: A Comparative Study between Korean and Non-Korean Perspectives. Indian Journal of Science and Technology. 2015;8(24). Available from: https://dx.doi.org/10.17485/ijst/2015/v8i24/80155.

34) Nithyavathi K. A Study on Safety and Welfare Measures Provided to the Employees in Textile Industry in Tirupur District. International Journal of Research in Management. 2016;6(10):51-60. Available from: https://d1wqtxts1xzle7.cloudfront.net/55339308.

35) Selaiyur C, Nadu T. Impact on Labour Welfare Measures in Spinning Mills at Dindugul District. .

36) Kumari AP, Kannan R. A study on statutory labour welfare measures in garment industry. International Journal for Research Trends and Innovation. 2018;3(2). Available from: http://www.ijrti.org/papers/IJRTI1802007.pdf.

37) Katuwal SB, Randhawa G. A study of job satisfaction of public and private sector Nepalese textile workers. Indian Journal of Industrial Relations. 2007;p. 239-53.

38) Rawat P, Jariwala MN. A Study on Welfare Activities Provided for Employees at Shree Durga Syntex Pvt Ltd. . 